\title{
Accounting Compliance of Amil Zakat Institutions for Financial Accountability
}

\author{
Ahmad Kudhori ${ }^{1}$, Hedi Pandowo ${ }^{2}$ \\ State Polytechnic Madiun, Serayu 84 Street, Madiun City ${ }^{1}$ \\ \{akudhori@pnm.ac.id ${ }^{1}$ \}
}

\begin{abstract}
The development of amil zakat institutions lately makes it easier for donors to donate without directly meeting the recipients, without reducing the meaning of the zakat worship. This research aim to determine background of the financial managers amilzakat institution as a form of compliance and accountability of the reports presented. The object of this research is amilzakat institution incorporated in Madiun Zakat Organization Forum, that is BAZNAS, LMI, LAZISMU, YatimMandiri, BMH, GlobalZakat, Nurul Hayat and Dompet Duafa. Descriptive qualitatif with multiple case study model was used as analysis in this research. Collecting data using in-depth interviews, observation and documentation to informants at each institution. It is shown in this study that educational background, years of service, and position lead cause understanding of accounting, financial reports and accounting standards from financial staff of the amil zakat institution to very different. However, the records carried out in relation to the transaction process to become financial reports as a form of transparency and accountability can run smoothly. This is because office governance, management and human resources in the institution can work together well.
\end{abstract}

Keywords: LAZ, Accountability, Accounting, Financial Statements, PSAK 109

\section{Introduction}

Accountability cannot be separated from accounting and management activities. Whether it's in the private business sector, corporations, organizations, even government. Public accountability is the obligation of individuals and organizations to present, report, disclose and account for all activities and activities that have been mandated to them. One of the important elements to report is finance. If within the scope of an organization or company, accountability will be made by the leadership and the parties holding the authority. Meanwhile, if accountability is made in the government dimension, then it is made by the executive at both the state and regional levels.

An organization that is profit-oriented or that is not profit-oriented, in running its organization requires an accountability report to those who need it. An organization is said to be accountable if it has the ability to explain the conditions it experiences, including the decisions it makes and the various activities it carries out. 
State revenue has been going on since the time of the prophet Muhammad SAW and continued during the time of Khurafatur Rashidin. Caliph Abu Bakr ash Siddiq fought against Muslims who did not pay their zakat and did not recognize their zakat obligations. During the time of the Caliph Umar bin Khattab, the financial management system of Baitul Maal was getting better. Every budget income and expenditure is recorded neatly and regularly, one of which is recording zakat income and expenditure. With an orderly, neat and good recording, zakat is not only a property that is issued as a cleanser for other assets, but there is another function of zakat, namely as a means of distributing wealth so that the gap between the rich and the poor gets smaller, where the rich can give their excess wealth. for the consumption of the poor. When the poor can meet their consumption, the long-term effect is economic stability, reduced crime rates and price stability [1].

BAZ and LAZ management model has been well implemented, but some problems and constraints that are still there, that is; 1) Obedience muzakki to pay zakat is not good enough, 2) Some people still don't understand zakat, even muslims still think that zakat is not mandatory, 3) There is no support from leadership of the institution to distribute their zakat through legal institutions, 4) There are no strict legal sanctions for muzakki who do not pay zakat, 5) The participation of existing resources has not been maximized, 6) limited human resources for collecting zakat, 7) Decreased trust of some people in the amil zakat institution, so that donations go directly to mustahik [2].

Some literatures state that amil zakat institution as a Faith Based Organization has the potential to provide many changes in the development process. This potential is not because LAZ has unique characteristics as an organization that serves people and also FBO, but in LAZ allows various development programs that can provide the best service to the community [3]. When the management of an institution is accountable, transparent, bureaucratic but not rigid, has quality standards and has clear targets, as well as quality objectives to be achieved, the institution can be said to be healthy [4].

Good zakat management system and transparent can realize accountability of an organization, including amil zakat institutions, which are expected to present financial reports in accordance with the applicable guidelines, that is according to the Statement of Financial Accounting Standards (PSAK) 109 concerning the Financial Statements of the Amil Zakat Institution, with a framework the basis of Statement of Financial Accounting Standar Number 101 concerning Commercial Sharia Institutions.

The amil zakat institution in Madiun area on process needs a community to be able to establish communication and share programs on the basis of common movements and steps related to zakat, donations and alms. This zakat forum was founded in 2018 and currently has 16 members, that is Baitul Maal Abdurrahman Bin Auf, NurulHayat, LAZISMU, YatimMandiri, LMI, BMH, DompetDuafa, BAZNAS, GlobalZakat, Al-Islah, Baitul Maal MBS Tarqu, DSUI, LDSPP, RumahZakat, Lazis Ar-Rohman, Baitul Maal Communication Forum.

Based on some of the explanations above, problem formulations can be made, that is how the accounting guidelines and preparation of financial reports can be understood and obeyed by financial management staff at amilzakat institution. This research is based on the formulation that has been made, making boundaries within the scope of the research, that is the case study of members from Madiun Raya Regional Organization Forum who have been designated as the National Amil Zakat Institute (LAZNAS), that is BAZNAS, NurulHayat, YatimMandiri, LMI, GlobalZakat, BMH, LAZISMU, Dompet Duafa. 


\section{Literatur Review}

The phenomenon that can be observed in the development of the public sector, especially amil zakat institution is increasing need for accountability to donors, so that their trust to continue channeling their funds to institutions is maintained. Accountability of public is obligation of the mandate holder to account for, provide, inform and reveal all activities that are responsibility has the right and authorities [4][5].

Public sector organizations must carry out public accountability which consists of several dimensions, that is:

a) Legal and honesty accountability, related to avoiding abuse office and in the use of public sources of funds, compliance with applicable laws and regulations must be ensured.

b) Process accountability, related to procedures used in performing tasks, whether administrative procedures, management information systems and accounting information systems are good enough.

c) Program accountability, related to objectives that have been set, whether it can be achieved and alternative programs with economical costs can provide maximum results, have also been considered.

d) Policy accountability, related to accountability of central and regional governments for policies taken towards DPR / DPRD and wider community [4].

Final product from processes of recording transaction and collect business transaction data is financial statements. Financial position, financial performance and cash flows of an entity are presented in a structured financial statement that is useful for making economic decisions [6]. As an information tool that connects the company with other parties, showing the company's financial health situation and company performance is a function of the financial statements. The purpose of financial reports is to provide information about financial position, performance and changes in financial position of a company that is useful for users in making economic decisions, besides that it also shows management accountability in managing the resources entrusted to it [7][8].

Financial reports have characteristics as distinctive features that make information in financial reports useful for user. According to IFRS there are 4 qualitative characteristics, that is comparable, understandable, reliable and relevant [9][10]. PSAK 109 concerning the Accounting for Zakat Infaq alms is foundation for non profit organizations, like amil zakat institutions. The financial reports this institution are different from the financial reports of private or profit oriented organizations.

The increasing of amilzakat institutions in Indonesia recently is increasingly developing as social movements. In fact, there is a gap between large zakat potential and very small zakat realization. This phenomenon show that performance of zakat management organizations is low. One of causes of low institutional performance is the lack of trust in potential donors in zakat management institutions. In addition, building public trust (potential donors) is an absolute requirement for organizations engaged in zakat, donations and alms.

\section{Research Methods}

Descriptive analysis with multiple case study models was used in this research. Object of research is national amilzakat institution which contributes to the collection and distribution of zakat, infaq, alms in Madiun and member from Madiun Regional Zakat Organization Forum. The are $16 \mathrm{LAZ}$ members in forum, but only LAZ that have national legality are taken. There 
are 8 LAZNAS, that is LAZISMU, BAZNAS, LMI, BMH, Yatim Mandiri, Global Zakat, Dompet Duafa and Nurul Hayat [11][12].

Data collection was carried out by in-depth interviews with 8 informants from each LAZ. Interviews were conducted during July - August 2020. Data analysis techniques were covered through 4 stages:

a) Data collection, namely in the form of data from interviews, observations, and documentation recorded in field notes which consist of two aspects, namely description and reflection.

b) Data reduction, namely selecting / simplifying the data obtained either from interviews, observations, or documentation based on the focus of the problem. After going through the data selection process, there will be important data and unused data. So, then the data is processed and presented in language and writing that is more scientific and more meaningful.

c) Data presentation, namely the process of displaying data from all research results in the form of tabular representative narrative exposure including matrix, graphic and so on, which later can make it easier for researchers to see the description of the research results because of the large amount of data and information the researcher has difficulty in making conclusions from the results of this study. The data obtained needs to be presented in a simpler format so that researchers can easily analyze them and take action based on the understanding obtained from presenting these data.

d) Data Inference, namely drawing conclusions in order to seek or understand meaning, regularity of explanatory patterns, flow of cause and effect. The conclusions that have been drawn are then verified by looking and questioning again and looking at the field notes in order to obtain a proper understanding. In addition, it can also be discussed [13].

\section{Research Result}

There are three things conducted in the interview, that is first, related with institution. Second, related to management of institutions in understanding reports of financial. Third, understanding of accounting.

To facilitate the discussion, it is further grouped into two parts, that is:

a. Describe the research informants.

b. Describe the results of the research and discussion

\subsection{Describe the Research Informants}

Tabel 1. Describe the Research Informants

\begin{tabular}{|c|c|c|c|c|c|c|c|c|c|}
\hline No & Information & Baznas & LMI & LazisMu & $\begin{array}{c}\text { Yatim } \\
\text { Mandiri }\end{array}$ & BMH & $\begin{array}{l}\text { Global } \\
\text { Zakat }\end{array}$ & Nurul Hayat & $\begin{array}{c}\text { Dompet } \\
\text { Duafa }\end{array}$ \\
\hline 1 & Nama & SH & PY & NKS & YP & AW & $\mathrm{RN}$ & EY & BW \\
\hline 2 & Job & $\begin{array}{l}\text { Financial } \\
\text { Planner }\end{array}$ & $\begin{array}{l}\text { Financial } \\
\text { Administra } \\
\text { tion }\end{array}$ & $\begin{array}{l}\text { Financial } \\
\text { Staff }\end{array}$ & $\begin{array}{l}\text { Financial } \\
\text { Staff }\end{array}$ & $\begin{array}{l}\text { Financial } \\
\text { Staff }\end{array}$ & $\begin{array}{l}\text { Financial } \\
\text { Administra } \\
\text { tion }\end{array}$ & $\begin{array}{l}\text { Financial } \\
\text { Administrati } \\
\text { on and } \\
\text { Accounting }\end{array}$ & Staf Umum \\
\hline 3 & $\mathrm{HP}$ number & $\begin{array}{l}08585241 \\
7689\end{array}$ & $\begin{array}{l}08135995 \\
3054\end{array}$ & $\begin{array}{l}08125245 \\
4505\end{array}$ & $\begin{array}{l}08564907 \\
0102\end{array}$ & $\begin{array}{l}08224753 \\
5408\end{array}$ & $\begin{array}{l}08223440 \\
6659\end{array}$ & $\begin{array}{l}085735645 \\
495\end{array}$ & $\begin{array}{l}085608797 \\
220\end{array}$ \\
\hline 4 & $\begin{array}{l}\text { Start } \\
\text { working }\end{array}$ & 2007 & 2010 & 2015 & 2011 & 2012 & 2019 & 2010 & 2018 \\
\hline 5 & $\begin{array}{l}\text { Start } \\
\text { Position }\end{array}$ & 2014 & 2016 & 2015 & 2011 & 2016 & 2019 & 2010 & 2018 \\
\hline 6 & Education & SMEA & $\begin{array}{l}\text { D3 } \\
\text { Fisioterapi }\end{array}$ & $\begin{array}{l}\text { S1 } \\
\text { Accoun- } \\
\text { ting } \\
\text { Education }\end{array}$ & $\begin{array}{l}\text { SMK } \\
\text { Computer } \\
\text { Technition }\end{array}$ & $\begin{array}{l}\text { S1 } \\
\text { Islamic } \\
\text { Education } \\
\text { Manage- } \\
\text { ment }\end{array}$ & $\begin{array}{l}\text { S1 } \\
\text { Science of } \\
\text { Nutrition }\end{array}$ & $\begin{array}{l}\text { D1 } \\
\text { Accounting }\end{array}$ & $\begin{array}{l}\text { SMK } \\
\text { Pnrbangan }\end{array}$ \\
\hline
\end{tabular}


From table 1 above, it can be explained that there are 3 institutions whose amil has a background in accounting education, namely LazisMu, Nurul Hayat and Baznas. Since entering institution until now, they served as financial staff. In terms of tenure, the financial staff who have only worked for around 1-2 years are Dompet Duafa and GlobalZakat, this is because these institutions were established in Madiun in 2018-2019.

\subsection{Describe the Results of the Research and Discussion}

Tabel 2. Institutional Discussion

\begin{tabular}{|c|c|c|c|c|c|c|c|c|c|}
\hline No & Information & Baznas & LMI & LazisMu & $\begin{array}{c}\text { Yatim } \\
\text { Mandiri }\end{array}$ & BMH & $\begin{array}{l}\text { Global } \\
\text { Zakat }\end{array}$ & Nurul Hayat & $\begin{array}{c}\text { Dompet } \\
\text { Duafa }\end{array}$ \\
\hline 1 & Nama & $\mathrm{SH}$ & PY & NKS & YP & AW & RN & $\mathrm{EY}$ & BW \\
\hline 2 & Job & $\begin{array}{l}\text { Financial } \\
\text { Planner }\end{array}$ & $\begin{array}{l}\text { Financial } \\
\text { Administra } \\
\text { tion }\end{array}$ & $\begin{array}{l}\text { Financial } \\
\text { Staff }\end{array}$ & $\begin{array}{l}\text { Financial } \\
\text { Staff }\end{array}$ & $\begin{array}{l}\text { Financial } \\
\text { Staff }\end{array}$ & $\begin{array}{l}\text { Financial } \\
\text { Administra } \\
\text { tion }\end{array}$ & $\begin{array}{l}\text { Financial } \\
\text { Administrati } \\
\text { on and } \\
\text { Accounting }\end{array}$ & Staf Umum \\
\hline 3 & HP number & $\begin{array}{l}08585241 \\
7689\end{array}$ & $\begin{array}{l}08135995 \\
3054\end{array}$ & $\begin{array}{l}08125245 \\
4505\end{array}$ & $\begin{array}{l}08564907 \\
0102\end{array}$ & $\begin{array}{l}08224753 \\
5408\end{array}$ & $\begin{array}{l}08223440 \\
6659\end{array}$ & $\begin{array}{l}085735645 \\
495\end{array}$ & $\begin{array}{l}085608797 \\
220\end{array}$ \\
\hline 4 & $\begin{array}{l}\text { Start } \\
\text { working }\end{array}$ & 2007 & 2010 & 2015 & 2011 & 2012 & 2019 & 2010 & 2018 \\
\hline 5 & $\begin{array}{l}\text { Start } \\
\text { Position }\end{array}$ & 2014 & 2016 & 2015 & 2011 & 2016 & 2019 & 2010 & 2018 \\
\hline 6 & Education & SMEA & $\begin{array}{l}\text { D3 } \\
\text { Fisioterapi }\end{array}$ & $\begin{array}{l}\text { S1 } \\
\text { Accoun- } \\
\text { ting } \\
\text { Education }\end{array}$ & $\begin{array}{l}\text { SMK } \\
\text { Computer } \\
\text { Technition }\end{array}$ & $\begin{array}{l}\text { S1 } \\
\text { Islamic } \\
\text { Education } \\
\text { Manage- } \\
\text { ment }\end{array}$ & $\begin{array}{l}\text { S1 } \\
\text { Science of } \\
\text { Nutrition }\end{array}$ & $\begin{array}{l}\text { D1 } \\
\text { Accounting }\end{array}$ & $\begin{array}{l}\text { SMK } \\
\text { Pnrbangan }\end{array}$ \\
\hline
\end{tabular}

Can be seen from table 2, that Baznas in 2014 get National title, followed by BMH in 2015 and LAZISMU, Global Zakat, NurulHayat, LMI, YatimMandiri and DompetDuafa in 2016. Institutionally, which is an entity itself and not a branch office or outlet in Madiun is Baznas, while LMI, Nurul Hayat, Yatim Mandiri, LAZISMU, Global Zakat, Dompet Duafa, and BMH are branch office or unit offices, this also affects on preparation of financial statements. For the preparation of financial reports, apart from Baznas, the compilation is systemized and centralized. They only make notes of cash in and out, then send the results of the input to the head office every month. In terms of controlling and evaluating performance, Nurul Hayat, Baznas and LazisMu make their own financial reports, while LMI, BMH, Dompet Duafa, YatimMandiri and GlobalZakat just make cash in report and cash out reports.

Tabel 3. Accounting and Financial Report

\begin{tabular}{|c|l|l|l|l|l|l|l|l|l|}
\hline $\begin{array}{c}\text { N } \\
0\end{array}$ & Information & Baznas & \multicolumn{1}{|c|}{ LMI } & LazisMu & $\begin{array}{c}\text { Yatim } \\
\text { Mandiri }\end{array}$ & BMH & $\begin{array}{r}\text { Global } \\
\text { Zakat }\end{array}$ & $\begin{array}{c}\text { Nurul } \\
\text { Hayat }\end{array}$ & $\begin{array}{c}\text { Dompet } \\
\text { Duafa }\end{array}$ \\
\hline 1 & $\begin{array}{l}\text { Do you } \\
\text { understand } \\
\text { accounting } \\
\text { and } \\
\text { financial } \\
\text { reports? }\end{array}$ & Yes & $\begin{array}{l}\text { Yes, ever } \\
\text { worked } \\
\text { at PNPM }\end{array}$ & Yes & Yes & Not & $\begin{array}{l}\text { Yes, not } \\
\text { to much }\end{array}$ & Yes & a little \\
\hline 2 & $\begin{array}{l}\text { Do you } \\
\text { know } \\
\text { about } \\
\text { accounting } \\
\text { cycle? }\end{array}$ & Yes & $\begin{array}{l}\text { Ya, but } \\
\text { not much }\end{array}$ & Yes & Yes & Not & $\begin{array}{l}\text { Just } \\
\text { knowing } \\
\text { that } \\
\text { accountin } \\
\text { gis } \\
\text { related to } \\
\text { debits and } \\
\text { credits }\end{array}$ & Yes & a little \\
\hline 3 & $\begin{array}{l}\text { Is it } \\
\text { keeping a } \\
\text { journal? }\end{array}$ & Yes & Not & Yes & Not & Not & Not & Yes & Not \\
\hline
\end{tabular}




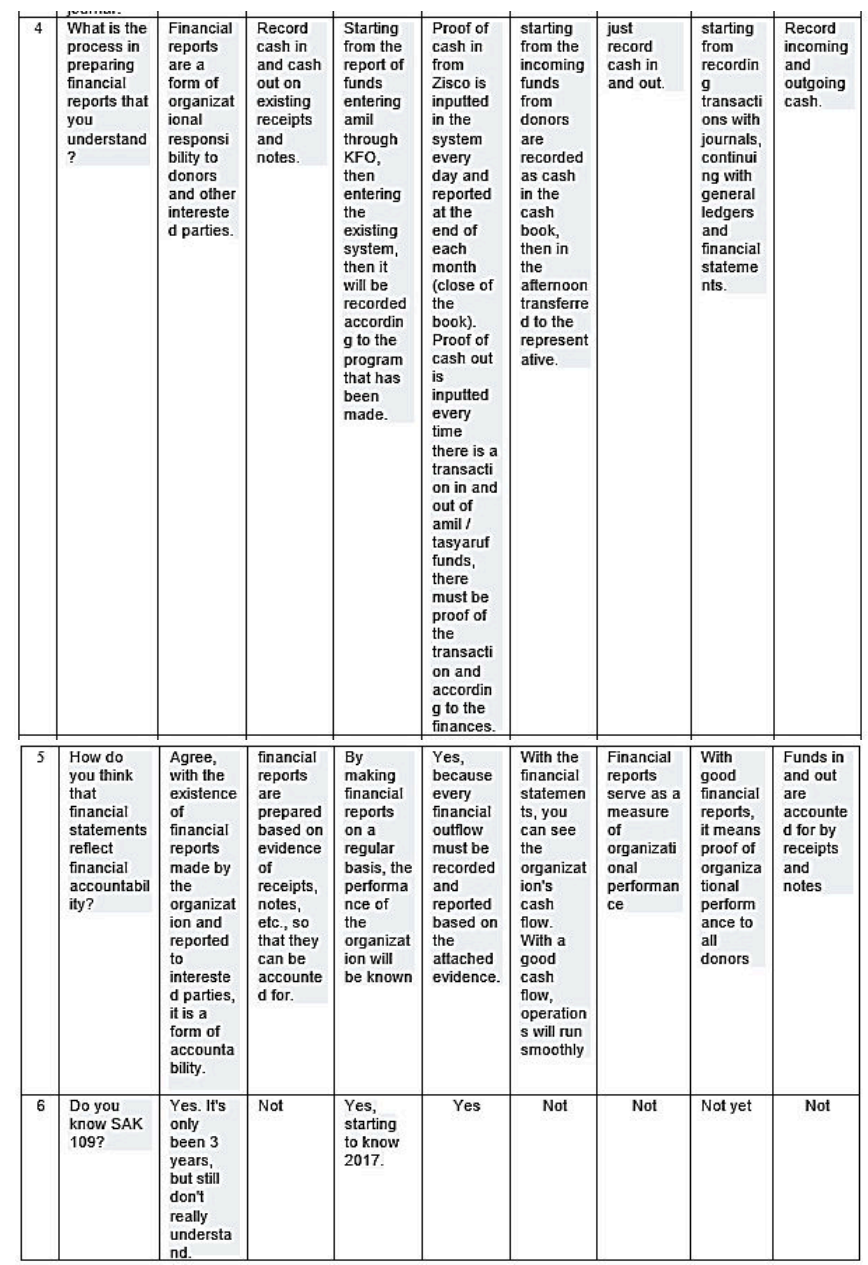

From table above, can be seen that related to understanding of accounting and financial reports as well as the accounting cycle, only BMH did not understand it, while others understood and had little understanding of Dompet Duafa. Regarding recording or keeping a journal, only Baznas, Lazismu and Nurul Hayat recorded transactions in the journal.

An understanding of the process of preparing financial statements shows, almost all say that the process begins with recording cash in and cash out, no one says process leads to preparation of financial statements as final result. Then understanding of financial reports reflects financial accountability, financial staff said that with good records, supported by valid proof of transactions, is a form of financial accountability for the institution.

Financial Accounting Standards (SAK) 109 as guidelines governing the accounting of amil, zakat and infaq institutions, are not yet known and known by most of the institution's financial staff. They only understand accounting and general financial reports. 


\section{Conclusion}

Financial statements cannot be separated from the name accounting. Both are interrelated and synergized parts as a process and an end result. Understanding of accounting certainly continue in the process of preparing financial statements as final result. Human resources at amilzakat institution have different work periods, different educational backgrounds, and different work intentions. However, even though their educational backgrounds are different and it is not related to the work they are doing, it does not stop from learning about financial governance these institutions. In addition, even though place and position of institution is in the regions, either as a unit office or branch office, it does not affect the running of institution, so that it continues as an actual organization. Governance of institutions, finance, offices, human resources and management in these institutions can synergize well, so that compliance of the amilzakat institution in recording which is beginning of an accounting process can produce output in form of financial reports. The recording process is carried out regularly and can run well, until a financial report is presented as a form of accountability and transparency to donors.

\section{Acknowledgements}

We would like to express our gratitude to all parties who have provided a lot of help, support and useful knowledge, so that this journal can be completed. Financial staff from LAZNAS who are members of FOZDA Madiun Raya, who have taken the time to interview, and also to the LAZNAS leadership who have given permission to be the object of research.

\section{References}

[1] R. A. Y. et Al, 'Analisis Perbedaan Harga Pembelian dan Kelangkaan Pupuk Bersubsidi Di kabupaten karo', J. Soc. Econ. Agric. Agribus., vol. 2, no. 3, 2013.

[2] I. R. dan A. S. Nanda, 'Transparansi Dan Akuntabilitas Laporan Keuangan Lembaga Amil Zakat: Perspektif Muzaki UPZ BNI Syariah', AKRUAL J. Akunt., vol. Vol 8, no. No 2 .

[3] A. A. S. Hidayat, 'Model Tata Kelola Badan dan Lembaga Amil Zakat Sebagai Upaya Untuk Meningkatkan Pemberdayaan Ekonomi Masyarakat (Studi Pada Badan / Lembaga Amil Zakat di Kota Malang)', J. Humanit., vol. Volume 7, no. Nomor 2, pp. $01-13$.

[4] V. S, 'Upaya Peneguhan Eksistensi Lembaga Amil Zakat Sebagai Salah Satu Bentuk Faith Based Organization di Indonesia.', J. Empati, vol. Volume 2, no. Nomor 1.

[5] S. N. Anggraeny, A. Kudhori, and T. Lestariningsih, 'Analisis Kinerja Keuangan dan Alokasi Belanja Modal Pemerintah Daerah', J. AKSI (Akuntansi dan Sist. Informasi), vol. 1, pp. 28-35, 2017.

[6] K. Mia, 'Membangun Kesehatan Organisasi Institusi Pendidikan Dokter: sebuah Transformasi menuju Akuntabilitas Sosial', MIMBAR, vol. Vol.31, no. No.1., pp. 123134.

[7] Mardiasmo, Public Sector Accounting. Yogyakarta: Andi., 2009.

[8] S. R. A. Satriawan, Akuntansi Keuangan versi IFRS, P.10. Yogyakarta: Graha Ilmu.

[9] I. A. Indonesia, 'Pernyataan Standar Akuntansi Keuangan No.109: Akuntansi Zakat Infak/Sedekah', 2011. 
[10] Hery, Akuntansi Pengantar I, P.13. Jakarta.: Bumi Aksara.

[11] R. L. Helliana, Sri Fadilah, Nurleli, 'Membangun Kepercayaan Konsumen: Faktor Penting Pada Lembaga Amil Zakat Seluruh Indonesia', 2012.

[12] N. R. Huda, Nurul,. Desti Anggraini, Khalifah MAYM, 'Prioritas Solusi Permasalahan Zakat Dengan Metode AHP (Studi di Banten dan Kalimantan)', J. Al-Iqtishad, vol. Vol. VI, no. No. 2.

[13] U. Husaini, Metodologi Penelitian Sosial. Jakarta: Bumi Aksara, 2009. 